\section{GC-MS ANALYSIS AND ANTIMICROBIAL ACTIVITY OF STEREOSPERMUM FIMBRIATUM AGAINST SELECTED SKIN-ASSOCIATED PATHOGENS}

Anis Fadhlina $a$, Md. Zaidul Islam Sarkerb, Fadzilah Adibah Abdul Majidc, Hassan I. Sheikh ${ }^{*}$

Institute of Food Security and Sustainable Agriculture, Universiti Malaysia Kelantan, 17600 Jeli, Kelantan, Malaysia

bFaculty of Pharmacy, International Islamic University Malaysia, Bandar Indera Mahkota, 25200 Kuantan, Pahang, Malaysia

Institute of Marine Biotechnology, Universiti Malaysia Terengganu, 21030 Kuala Nerus, Terengganu Darul Iman, Malaysia

dFaculty of Fisheries and Food Science, Universiti Malaysia Terengganu, 21030 Kuala Nerus, Terengganu Darul Iman, Malaysia
Article history

Received

30 April 2021

Received in revised form

15 July 2021

Accepted

21 July 2021

Published online

20 August 202

*Corresponding author sheikh@umt.edu.my

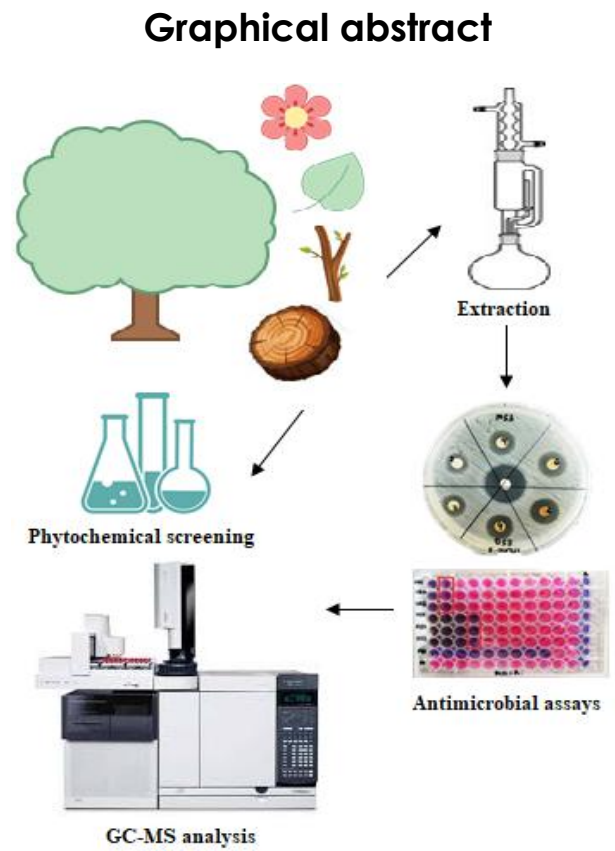

\begin{abstract}
Stereospermum fimbriatum (local name: "Chicha") has been used traditionally to treat postpartum illness, stomachache, earache and itchy skin in Malaysia. This study was performed to investigate the phytochemical contents of $S$. fimbriatum (flowers, leaves, twig and stem bark) by phytochemicals screening and GC-MS analysis as well as to determine their antimicrobial potential against eleven skin-associated pathogens. The extraction was done by soxhlet extractor using $n$-hexane (Hex), dichloromethane (DCM) and methanol, successively. The antimicrobial activity of all extracts was screened by disc diffusion assay and selected active extracts were evaluated for their minimum inhibitory and bactericidal concentration (MIC \& MBC). Phytochemicals such as steroids, terpenoids, tannins, flavonoids and saponins were identified in different plant parts of S. fimbriatum. Hex and DCM extracts of stem bark were the most potent extracts especially against three susceptible pathogens, methicillin-resistant Staphylococcus aureus (13-15 mm), S. aureus (14-15 mm) and S. epidermidis (16 $\mathrm{mm}$ ). The range of MIC values for Hex and DCM extracts was 0.4 to $0.8 \mathrm{mg} / \mathrm{mL}$. GC-MS analysis of Hex and DCM extracts showed the presence of numerous bioactive compounds. The stem bark of $S$. fimbriatum was rich of bioactive compounds and exhibited potent antibacterial activity specifically against Staphylococci sp.
\end{abstract}

Keywords: Stereospermum fimbriatum, Bignoniaceae, Chicha, skin infection, antibacterial, GC-MS 


\begin{abstract}
Abstrak
Stereospermum fimbriatum (nama tempatan: "Chicha") telah digunakan secara tradisional untuk merawat penyakit selepas bersalin, sakit perut, sakit telinga dan kulit gatal di Malaysia. Kajian ini dilakukan untuk menyiasat kandungan fitokimia S. fimbriatum (bunga, daun, ranting dan kulit batang) dengan pemeriksaan fitokimia dan analisis GC-MS serta untuk menentukan potensi antimikrobial mereka terhadap sebelas patogen kulit. Pengekstrakan dilakukan oleh pengekstrak soxhlet menggunakan n-heksana (Hex), diklorometana (DCM) dan metanol, berturut-turut. Aktiviti antimikrobial dari semua ekstrak disaring dengan ujian penyebaran cakera dan ekstrak aktif yang dipilih dinilai untuk kepekatan minimum perencatan dan bakterisidal (MIC \& MBC). Fitokimia seperti steroid, terpenoid, tanin, flavonoid dan saponin dikenal pasti di bahagian tumbuhan S. fimbriatum yang berbeza. Hex dan DCM ekstrak dari kulit batang adalah ekstrak yang paling kuat terutamanya terhadap tiga patogen yang rentan, Staphylococcus aureus yang tahan methicillin (13-15 $\mathrm{mm})$, S. aureus $(14-15 \mathrm{~mm})$ dan $\mathrm{S}$. epidermidis $(16 \mathrm{~mm})$. Julat nilai MIC untuk ekstrak Hex dan DCM adalah 0.4 hingga $0.8 \mathrm{mg} / \mathrm{mL}$. Analisis GC-MS ekstrak Hex dan DCM menunjukkan adanya sebilangan besar sebatian bioaktif. Kulit batang S. fimbriatum kaya dengan sebatian bioaktif dan menunjukkan aktiviti antibakterial yang kuat khususnya terhadap Staphylococci sp.
\end{abstract}

Kata kunci: Stereospermum fimbriatum, Bignoniaceae, Chicha, jangkitan kulit, antibakterial, GC-MS

\subsection{INTRODUCTION}

Staphylococci species are among the dominant skin colonizer which caused most of the nosocomial skin infection worldwide. This issue has become a substantial global burden by the association of its treatment to the widespread of multiple drug resistance [1]. This occurrence leads to severe infections in which patients have $64 \%$ more chance to die compared to infected patients with a nonresistant strain [2]. Given this alarming status, there is a constant need to look for new and effective antimicrobial agents. This may require the use of sustainable development of drug discovery by preserving available natural resources of our medicinal plants as they are renewable sources and thus enabling the concept of sustainability in future drug discovery [3].

Plants are among the exemplary source of medicines used by mankind for ages. However, the biological activities of most ethno-medicinal plants have not properly been scientifically validated [4]. Stereospermum fimbriatum is one of the unexploited species which belongs to Bignoniaceae family. It has a local name known as "Chicha" and sometimes it is also called as "snake tree" due to its snake-like coiled fruits. S. fimbriatum's shoot has been used traditionally to treat stomachache while its root is used to aid the postpartum recovery. Moreover, in Malaysia, juice of S. fimbriatum's leaves was used traditionally to treat earache and also can be mixed with lime to place on the itchy skin [5-6]. However, limited scientific studies [7-8] have been carried out to prove its traditional claims, especially in treating skin diseases. The present study was designed to screen the phytochemical contents of S. fimbriatum's flower, leave, twig and stem bark as well as to identify their bioactive compounds in the active extracts through GC-MS analysis and investigate the antimicrobial potentials against eleven skin pathogens.

\subsection{METHODOLOGY}

\subsection{Plant Collection and Preparation}

Fresh samples of different plant parts (leaves, flower, stem bark and twig) of $S$. fimbriatum were acquired from Pasir Mas, Kelantan. The plant authentication was done by a certified botanist with voucher specimen number: PIIUM 0249. The samples were immediately cleaned from any dirt and dried at room temperature for a week. After the samples were completely dried, grinding process was done to produce fine powders of samples and stored at $4{ }^{\circ} \mathrm{C}$ [9].

\subsection{Phytochemical Analysis}

\subsubsection{Alkaloid}

A thick slurry was formed by mixing the ground sample (3 g) with chloroform. The addition of 
ammoniacal chloroform (10 mL) into the slurry was done and the mixture was filtered. The formation of an aqueous layer was observed upon addition of 1 $\mathrm{mL}$ of $1 \mathrm{M} \mathrm{H} 2 \mathrm{SO} 4$. The aqueous layer was transferred into a test tube and Mayer's reagent was added. The presence of alkaloid was indicated by the observation of white to cream precipitation [10].

\subsubsection{Terpenoid and Steroid}

A mixture of the ground sample $(3 \mathrm{~g})$ and ethanol $(90 \mathrm{~mL})$ was boiled. The boiled mixture was filtered into a test tube $(20 \mathrm{~mL})$ and the ethanol was evaporated. The mixture leftover was used for tannin, flavonoid and saponin tests. Upon evaporation of the ethanol, diethyl ether $(10 \mathrm{~mL})$ was added a spot plate and left to dry. Then, a small amount of acetic anhydride was dropped onto the plate followed by concentrated $\mathrm{H}_{2} \mathrm{SO}_{4}$. The presence of terpenoid and steroid was indicated by blue and purple colour formation, respectively [11].

\subsubsection{Flavonoid}

The mixture leftover $(20 \mathrm{~mL})$ obtained from 2.2.2 test was used upon the evaporation of ethanol. The resultant extract was rinsed with $10 \mathrm{~mL}$ petroleum ether and $80 \%$ ethanol $(10 \mathrm{~mL})$ was added. Few pieces of magnesium coils were put into the solution and concentrated $\mathrm{HCL}(0.5 \mathrm{~mL})$ was added. After 10 minutes, the presence of flavonoid was determined by orange to red colour formation [12].

\subsubsection{Saponin}

The mixture leftover $(20 \mathrm{~mL})$ obtained from 2.2.2 test was added with distilled water. The solution was shaken for a few minutes vigorously. After 15-20 min, the formation of froth was observed to determine the presence of saponin [13].

\subsubsection{Tannin}

The mixture leftover $(1 \mathrm{~mL})$ obtained from 2.2.2 test was added with distilled water $(2 \mathrm{~mL})$ followed by addition of ferric chloride ( $\mathrm{FeCl} 3$ ) solution (2-3 drops). The observation of blue-black (gallic tannins) or green to blue-green (cathectic tannins) coloration was recorded [11].

\subsection{Soxhlet Extraction}

Extraction thimbles were filled with ground samples $(50 \mathrm{~g})$ and placed into the soxhlet extractor. Solvents of increasing polarity (n-hexane, dichloromethane (DCM) and methanol) were successively used in the soxhlet extraction. The extraction was completed when the solvents turned colourless (6-8 h). Concentrated crude extracts were obtained after removing the solvent using vacuum rotary evaporator and weighted prior to storage at $4{ }^{\circ} \mathrm{C}$ [14].

\subsection{Microorganisms}

11 different strains of human skin-associated pathogens were tested such as methicillin-resistant Staphylococcus aureus (MRSA), Streptococcus pyogenes (ATCC 19615), S. epidermidis (ATCC 12228), S. aureus (ATCC 25923), Bacillus cereus (ATCC 11778), Pseudomonas aeruginosa (ATCC 27853), Escherichia coli (ATCC 25922), Enterococcus aerogenes (ATCC 13048), Proteus vulgaris (ATCC 6380), Candida albicans (IMR C 523/11 A) and Microsporum gypseum (ATCC 24102). Inoculum was prepared using 0.5 McFarland standard at $625 \mathrm{~nm}$ (bacteria) and $595 \mathrm{~nm}$ (fungi) [15]. Single colonies of each microorganism were obtained and transferred into the growth media. The incubation was done at $37^{\circ} \mathrm{C}$ (18-24 hours) and $30^{\circ} \mathrm{C}$ (24-48 hours) for the bacteria and fungi, respectively.

\subsection{GC-MS derivatization Method}

Derivatization of the extract was conducted by methoxyamination and trimehthylsilylation methods. Briefly, a stock solution of methoxyamine hydrochloride $(20 \mathrm{mg} / \mathrm{mL})$ was prepared in pyridine. Addition of pyridine $(50 \mu \mathrm{L})$ into $1.5 \mathrm{mg}$ of extract was done followed by sonication of the mixture at $30^{\circ} \mathrm{C}$ (10 min). Then, addition of methoxyamine hydrochloride solution $(100 \mu \mathrm{L})$ into the mixture was done and further incubated at $60^{\circ} \mathrm{C}$ (2 hours). After the incubation period, $100 \mu \mathrm{L}$ of derivatizing agent viz., $\quad \mathrm{N}$-Methyl-N-(trimethylsilyl)trifluoroacetamide (MSTFA) was added into the mixture and incubated at $60{ }^{\circ} \mathrm{C}$ (30 min). The mixture was kept at room temperature overnight to allow for a complete chemical reaction prior to filtration of the mixture [16].

\subsection{GC-MS Analysis}

The derivatized extract was injected $(1 \mu \mathrm{L})$ into the inlet of column. Helium as a carrier gas was used for GC-MS analysis. In the GC-MS analysis of NS, the initial oven temperature was $90{ }^{\circ} \mathrm{C}$, and gradually heated up to $175^{\circ} \mathrm{C}\left(8^{\circ} \mathrm{C} / \mathrm{min}\right.$, hold $\left.2 \mathrm{~min}\right)$, 175 $235^{\circ} \mathrm{C}\left(3^{\circ} \mathrm{C} / \mathrm{min}\right.$, hold $\left.10 \mathrm{~min}\right), 235-275^{\circ} \mathrm{C}\left(3^{\circ} \mathrm{C} / \mathrm{min}\right.$, hold $10 \mathrm{~min})$ and $275-315^{\circ} \mathrm{C}\left(3^{\circ} \mathrm{C} / \mathrm{min}\right.$, hold $\left.10 \mathrm{~min}\right)$. The initial oven temperature for GC-MS analysis of DS was $90^{\circ} \mathrm{C}$, increased to $165^{\circ} \mathrm{C}\left(5^{\circ} \mathrm{C} / \mathrm{min}\right)$, hold for 2 min and for every transition of 165 to $235^{\circ} \mathrm{C}, 235$ to $275^{\circ} \mathrm{C}$ and 275 to $315^{\circ} \mathrm{C}$, an increase of $3{ }^{\circ} \mathrm{C} / \mathrm{min}$ and $10 \mathrm{~min}$ hold was done. In the identification of compounds, MS data with $>70 \%$ library match (Wiley library) was considered for the selection.

\subsection{Disc Diffusion Method}

Gentamycin (10 $\mathrm{\mu g} / \mathrm{disc})$ and vancomycin 130 $\mu \mathrm{g} /$ disc) were used as the positive controls for bacteria while nystatin $(100 \mu \mathrm{g})$ was used for the positive control of fungi. The diluent used to dissolve the extracts (50\% DMSO (v/v) in distilled water) was used as a negative control. Mueller-Hinton agar 
(MHA) was used as the growth media for bacterial while Sabouraud-Dextrose agar (SDA) was used as the fungi's growth media. Blank discs (diameter: 5 $\mathrm{mm})$ were loaded with extracts at concentration of $200,400,600 \mu \mathrm{g} /$ disc. Cultures $(100 \mu \mathrm{L})$ adjusted to 0.5 McFarland standard were spread on the media and the loaded discs were laid on the inoculated media surface and then incubated. Standard antibiotics and negative control were tested in a similar manner as stated. All the extracts were tested in triplicates and the inhibition zone was recorded with their means and standard deviation [17].

\subsection{Microdilution Assays}

A range of concentrations $(1000,800,600,400,200$, 100,50 and $25 \mu \mathrm{g} / \mathrm{mL}$ ) was prepared from $10 \mathrm{mg} / \mathrm{mL}$ of stock sample and transferred into respective wells of microtiter plate. Inoculum with a density equal to 0.5 McFarland $(1 \times 108 \mathrm{CFU} / \mathrm{mL})$ standard was prepared and further diluted with the media (culture to media ratio; 1 to 20). The diluted inoculum $\left(5 \times 10^{6}\right)$ was transferred $(10 \mu \mathrm{L})$ into each well with the inoculum final concentration of $5 \times 10^{5}$ and $100 \mu \mathrm{L}$ of final volume for each well. The plate was incubated for $24 \mathrm{~h}$ at $37^{\circ} \mathrm{C}$. The last well was loaded with broth only for sterility control. [15].

The standard antibiotics (gentamycin and vancomycin) were tested as a positive control in a two-fold serial dilution (100 - $0.098 \mu \mathrm{g} / \mathrm{mL}$ ). The negative control used in this study was $50 \%$ DMSO. After the incubation period, $0.01 \%$ (wt/v) resazurin sodium salt ( $30 \mu \mathrm{L})$ was loaded into each well. Then the treated culture was incubated for another two hours. Minimum Inhibitory concentration (MIC) value was recorded as the lowest concentration that maintained the blue colour of resazurin (Chuah et al., 2014). Treated cultures containing concentrations equal to and higher than the MIC value were transferred $(100 \mu \mathrm{L})$ and swabbed onto the agar plate. The concentration that gave zero subculture growth on the agar after the incubation period was considered as Minimum Bactericidal Concentration (MBC) [15].

\subsection{Statistical Analysis}

Statistical analysis was done using IBM SPSS Statistics 20. Results were expressed as means of triplicate readings \pm standard deviation (SD). The means were considered significantly different at $p<0.05$ by oneway ANOVA analysis.

\subsection{RESULTS AND DISCUSSION}

The soxhlet extraction of $S$. fimbriatum gave the highest percentage of yield for methanol extracts $(6.26-27.02 \%)$ specifically on the flower and stem bark (Table 1). The lowest percentage of yield was observed for all solvent extracts of twig $(0.32-6.26 \%)$.
Phytochemicals screening of the different parts of $S$. fimbriatum showed a variety of phytochemicals such as flavonoids, terpenoids, saponins steroids and tannins (Table 2). However, alkaloid was not detected in all parts. The flowers and leaves contained the highest variety of phytochemicals. The stem bark of S. fimbriatum was found to have only steroid and tannin among tested phytochemicals.

Table 1 Soxhlet extraction yields of S. fimbriatum's extracts

\begin{tabular}{lllllll}
\hline Sample & $\begin{array}{l}\text { Hex } \\
(\mathbf{g})\end{array}$ & $\begin{array}{l}\text { Yield } \\
(\mathbf{\%})\end{array}$ & $\begin{array}{l}\text { DCM } \\
\mathbf{( g )}\end{array}$ & $\begin{array}{l}\text { Yiel } \\
\mathbf{d} \\
(\mathbf{\%})\end{array}$ & $\begin{array}{l}\text { Met } \\
\mathbf{( g )}\end{array}$ & $\begin{array}{l}\text { Yield } \\
(\mathbf{\%})\end{array}$ \\
\hline $\begin{array}{l}\text { Stem } \\
\text { bark }\end{array}$ & 0.16 & 0.32 & 0.31 & 0.62 & 11.32 & 22.64 \\
\hline Twig & 0.16 & 0.32 & 0.13 & 0.26 & 3.13 & 6.26 \\
\hline Leave & 0.93 & 1.86 & 0.34 & 0.68 & 4.67 & 9.34 \\
\hline Flower & 0.91 & 1.82 & 0.30 & 0.6 & 13.51 & 27.02 \\
\hline
\end{tabular}

Hex: $n$-hexane; DCM: Dichloromethane; Met: Methanol

Table 2 Phytochemicals screening result of $S$. fimbriatum.

\begin{tabular}{lcllccc}
\hline Sample & Alk & Terp & Ster & Flav & Sap & Tan \\
\hline Flower & - & ++ & +++ & +++ & + & $+\mathrm{CT}$ \\
Leave & - & +++ & +++ & +++ & ++ & $+\mathrm{CT}$ \\
Stem & - & - & + & - & - & $+\mathrm{CT}$ \\
bark & & & & & & \\
Twig & - & + & + & - & + & $+\mathrm{CT}$ \\
\hline${ }_{+}:$Weak; ${ }^{++}:$Moderate; ${ }^{+++}$: Abundant; : Not detected; ${ }^{+C T}$ : Cathectic
\end{tabular}
tannins detected

However, stem bark of closely related species such as S. chelonoides [18], S. suaveolens [19-20] and S. kunthianum [21] was reported to possess a variety of phytochemicals such as alkaloids, flavonoids, steroids, tannins and saponins. These previous studies were mostly done on crude extracts or fractions compared to raw materials used in the present study which may explain the difference in the phytochemical contents. The use of the raw materials was necessary as the traditional practices are reported on the application of the raw materials [5-6], while the standard phytochemicals screening methods used in this study are for the raw materials. However, future studies could be done on the crude extracts such as methanol extract.

There was no antimicrobial activity observed in the present study of all extracts against two fungi strains, Candida albicans and Microsporum gypseum, as well as against six bacteria strains, Escherichia coli, Streptococcus pyogenes, Proteus vulgaris, Bacillus cereus, Pseudomonas aeruginosa and Enterococcus aerogenes. There were three susceptible strains observed which were S. epidermidis, MRSA and S. aureus (Table 1S). DCM extract was the most potent extract with the largest zone of inhibition against $S$. epidermidis $(16 \mathrm{~mm})$, followed by MRSA and $S$. aureus $(15 \mathrm{~mm})$ at $600 \mu \mathrm{g} /$ disc. The second most potent extract was n-hexane (Hex) extract of stem 
bark against $S$. epidermidis $(16 \mathrm{~mm})$, MRSA $(13 \mathrm{~mm})$ and $S$. aureus $(13.67 \mathrm{~mm})$ at $600 \mu \mathrm{g} / \mathrm{disc}$.

The zone of inhibition for methanol extracts of leaves, stem bark and twig was in the range of 7.67 $10.67 \mathrm{~mm}$. As for the S. fimbriatum's flower, its methanol extract showed no antimicrobial activity against all strains. The flower extracts only showed small or partial inhibition zones against MRSA and $S$. epidermidis. A previous study on n-hexane extract of $S$. chelonoides's stem bark reported that the tested extracts were active against $P$. aeruginosa, $S$. aureus, E. coli and C. albicans (12-21 mm of inhibition zones) at $250 \mu \mathrm{g} /$ disc [22]. Meanwhile, in a study reported on methanol extract of $S$. personatum's stem bark, less antimicrobial activity $(8-13 \mathrm{~mm})$ was observed against the same strains at $400 \mu \mathrm{g} /$ disc [23]. Thus, the present findings had showed a similar pattern of observations with the previous findings of which Hex extract of the stem bark exhibited more potent antibacterial activity as compared to the methanol extract. All active extracts showed selective inhibition on the growth of Gram-positive bacteria, Staphylococcus species. It is interesting to note that the effective inhibition activity was observed against one of the dreadful pathogens which is MRSA, one of the major causes of nosocomial infections [24].

Extracts with inhibition zone $\geq 13 \mathrm{~mm}$ are categorized as potent extracts [25]. Hex and DCM extracts met the aforementioned criterion and therefore were selected for MIC test against S. aureus, MRSA and S. epidermidis. An extract with a MIC value less than $1 \mathrm{mg} / \mathrm{mL}$ can be considered as a potential therapeutic agent [26]. In this study, the MIC values of Hex and DCM was as in the range of $0.4-0.8 \mathrm{mg} / \mathrm{mL}$ against MRSA, $S$. aureus and $S$. epidermidis. Meanwhile, the MBC value of Hex and DCM were in the range of $0.4-1 \mathrm{mg} / \mathrm{mL}$. This may indicate that $S$. fimbriatum is a potential candidate plant for the development of antimicrobial drugs.

GC-MS analysis was conducted on the two most active extracts, DCM and Hex, to identify their bioactive compounds. There were 25 compounds (Table 2S) with $>70 \%$ library match identified in the GC-MS profile of Hex extract (Figure 1) with a high amount of fatty acids and monoglycerides such as 1monopalmitin $(20.65 \%)$, palmitic acid $(10.50 \%)$, oleic acid $(10.29 \%)$, stearic acid $(6.67 \%)$ and linoleic acid $(4.83 \%)$. Other major compounds were $\beta$-sitosterol (10.28\%) and 3-aza-A-homocholest-4a-en-4-one (11.91\%). As for the GC-MS profile of DCM extract (Figure 2), there were 53 compounds identified as shown in Table 3S. The GC-MS profile of DCM extract showed similar major compounds but with lower abundance compared to Hex extract such as 1monopalmitin (Hex: $20.65 \%$ \& DCM: $11.73 \%$ ), palmitic acid (Hex: $10.5 \%$ \& DCM: $3.18 \%$ ), and $\beta$-Sitosterol (Hex: $10.28 \%$ \& DCM: $1.33 \%$ ) which might indicate the leftover of the compounds that had not been completely extracted from the hexane extraction.

The presence of this similar major compound might suggest the need to extend the extraction time (>8 hours) to allow complete extraction before increasing the solvent polarity. However, other compounds may be degraded from the extension of time. Hence, it is suggested that the extraction method to be optimized in order to maximize the recovery of active compounds. There were other major compounds identified in the DCM extract such as vanillyl alcohol (6.92\%) and p-coumaric acid $(10.99 \%)$ as well as 4-hydroxy-3methoxyphenethylene glycol, ferulic acid, octadecanoic acid, palmitic acid, 10,10-dimethyl-9oxa-10-sila-9,10-dihydrophenanthrene, tyrosol and 4(N-Methylamino)-6,7-(1,2,3,4-tetrahydro-1,1,4,4tetramethylbenzo)indole in the range of 2.80 to $4.93 \%$.

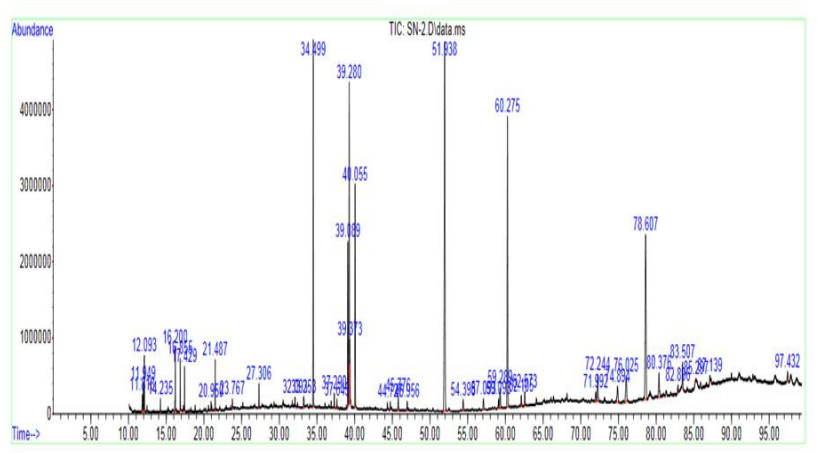

Figure 1 GC-MS profile of S. fimbriatum's stem bark ( $n$ hexane extract)

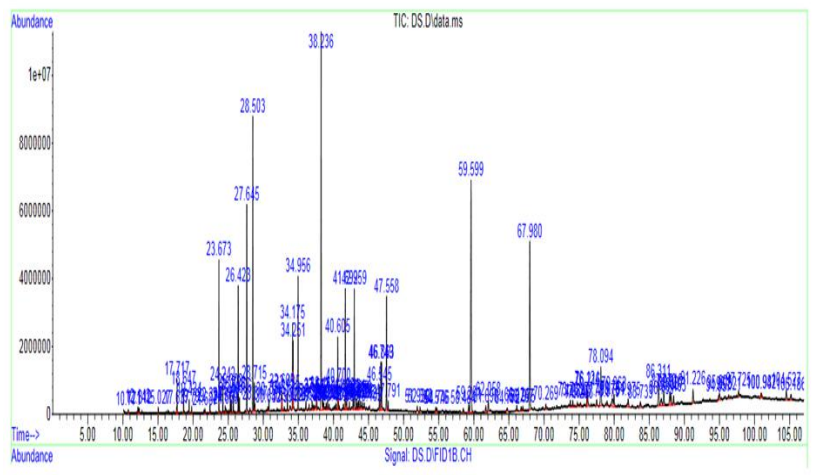

Figure 2 GC-MS profile of S. fimbriatum's stem bark (DCM extract)

The presence of abundant and diverse compounds in the DCM extract may also explain the significantly higher antibacterial activity of DCM extract as compared to Hex extract. Antibacterial activity of both Hex and DCM extract can be correlated to the detected antimicrobial compounds such as 1-monopalmitin [27], tyrosol [28], ferulic acid, vanillic acid, p-coumaric acid, caffeic acid, syringic acid [29], stearic acid, linoleic acid, palmitic acid, oleic acid [30], arachidic acid [31], $\beta$-sitosterol [32], campesterol and stigmasterol [33]. In sum, fatty acids, sterols, phenolic acids, monoglycerides and hydrocarbons were identified in the stem bark of $S$. fimbriatum. The strong antimicrobial activity of stem bark was in line with previous studies where stem bark 
is the most plant part that has been studied in the literature of Stereospermum genus. A broad range of microorganisms with at least 27 pathogens were reported to be susceptible to the stem bark extracts of Stereospermum genus [6].

Though the present study has shown that there was less variety of phytochemicals detected in the stem bark compared to flowers and leaves, numerous antimicrobial compounds were identified through the GC-MS analysis of stem bark extract which may explain the observed antibacterial activity. The antimicrobial activity did not correlated with the phytochemical screening results as phytochemical richness of the leaves and flowers did not result in high antimicrobial activity. This indicated that these plant parts could be rich in compounds with bioactivities other than antimicrobial. Moreover, stem bark showed less phytochemical variety and high antimicrobial activity. This indicated that the active compounds might belong to phytochemical classes other than the selected standard classes. This hypothesis was later confirmed by GCMS analysis in this study as the active extracts contain high amounts of fatty acids that were not screened for. Previous studies showed that fatty acids inhibit Staphylococcus strains, especially MRSA, S. aureus and S. epidermidis [34]. A recent study [7] on the antimicrobial activity of S. fimbriatum's stem bark also identified an anti MRSA compound which belonged to anthraquinones family. Hence, future studies on $S$. fimbriatum should consider quinones and other classes for the phytochemical screening.

\subsection{CONCLUSION}

Overall, different parts of $S$. fimbriatum exhibited multiple degrees of antibacterial activity. The most potent extract was found to be the DCM extract of stem bark especially against MRSA, S. epidermidis, and $S$. aureus. Further studied on its mechanism of action against susceptible pathogens, specifically MRSA, are needed in order to evaluate the potential pathways that are responsible for the demonstrated activity. Furthermore, studies on the leaves and flowers may be carried out to evaluate their potential for other bioactivities such as anticancer, antioxidant, anti-diabetic and anti-inflammatory since they were found to have a variety of phytochemicals.

\section{Acknowledgement}

The work was partially funded by Talent and Publication Enhancement Research Grant (TAPE-RG) No. 55217 from University Malaysia Terengganu.

\section{References}

[1] Taylor, T. A., \& Unakal, C. G. 2017. Staphylococcus aureus; StatPearls. Publishing: Treasure Island, FL, USA.
[2] World Health Organization (WHO). 2020. Antimicrobial resistance. Retrieved from https://www.who.int/newsroom/fact-sheets/detail/antimicrobial-resistance.

[3] Howes, M. J. R., Quave, C. L., Collemare, J., Tatsis, E. C., Twilley, D., Lulekal, E., Farlow, A., Li, L., Cazar, M. E., Leaman, D. J., and Prescott, T. A. 2020. Molecules from Nature: Reconciling Biodiversity Conservation and Global Healthcare Imperatives for Sustainable Use of Medicinal Plants and Fungi. Plants, People, Planet. 2(5): 463-481.

[4] Eldeen, I. M. S., Effendy, M. A. W., and TengkuMuhammad, T. S. 2016. Ethnobotany: Challenges and Future Perspectives. Research Journal of Medicinal Plants. 10: 382-387.

[5] Quattrocchi, U. 2012. CRC World Dictionary of Medicinal and Poisonous Plants: Common Names, Scientific Names, Eponyms, Synonyms, and Etymology (5 Volume Set). Taylor \& Francis Group, CRC Press, US. 4: 2570.

[6] Anis, F. I. A., Sahena, F., Zaidul, I. M., Hassan, I. S., Ghafoor, K., and Kamaruzzaman, B. Y. 2016. Stereospermum fimbriatum as a Potential Source of Phytochemicals: A Review of Stereospermum Genus. Current Pharmaceutical Biotechnology. 17(12): 1024-1035.

[7] Awang, A. F. I., Ahmed, Q. U., Shah, S. A. A., Jaffri, J. M., Ghafoor, K., Uddin, A. H., Ferdosh, S., and Islam Sarker, M. Z. 2020. Isolation and Characterization of Novel Antibacterial Compound from an Untapped Plant, Stereospermum fimbriatum. Natural Product Research. 34(5): 629-637.

[8] Fadhlina, A., Islam Sarker, M. Z., Ahmed, Q. U., Jaffri, J. M., Sheikh, H. I., and Ferdosh, S. 2020. Enrichment of Antibacterial Compound from the Stem Bark of Stereospermum Fimbriatum using Supercritical Carbon Dioxide Extraction. Separation Science and Technology. 55(9): 1656-1666.

[9] Saad, S., Taher, M., Susanti, D., Qaralleh, H., \& Awang, A. F. I. B. 2012. In Vitro Antimicrobial Activity of Mangrove Plant Sonneratia alba. Asian Pacific Journal of Tropical Biomedicine. 2(6): 427-429.

[10] Hadi, S., and Bremner, J. B. 2001. Initial Studies on Alkaloids from Lombok Medicinal Plants. Molecules. 6: 117-129.

[11] Talukdar, A. D., Choudhury, M. D., Chakraborty, M., and Dutta, B. K. 2010. Phytochemical Screening and TLC Profiling of Plant Extracts of Cyathea gigantea (Wall. Ex. Hook.) Haltt. and Cyathea brunoniana. Wall. ex. Hook. (Cl. \& Bak.). Assam University Journal of Science and Technology. 5(1): 70-74.

[12] Yadav, R. N. S. and Agarwala, M. 2011. Phytochemical Analysis of Some Medicinal Plants. J Phytology. 3(12): 1014.

[13] Tiwari, P., Kumar, B., Kaur, M., Kaur, G. and Kaur, H. 2011. Phytochemical Screening and Extraction: A Review. I Pharm Sciencia. 1 (1): 98-106.

[14] Saad, S., Taher, M., Susanti, D., Qaralleh, H., Noorhaidi, N., and Awang, A. F. B. 2013. Antimicrobial Activity of Mangrove Plant Acrostichum Speciosum. Journal of Pure and Applied Microbiology. 7: 253-257.

[15] Clinical and Laboratory Standards Institute (CLSI). 2012. Methods for Dilution Antimicrobial Susceptibility Tests for Bacteria that Grow Aerobically; Approved Standard. Ninth Edition. Jan; M07-A9, 32:2.

[16] Robinson, A. R., Gheneim, R., Kozak, R. A., Ellis, D. D., and Mansfield, S. D. 2005. The Potential of Metabolite Profiling as a Selection Tool for Genotype Discrimination in Populus. Journal of Experimental Botany. 56(421): 2807-2819.

[17] Clinical and Laboratory Standards Institute (CLSI). 2014. Performance Standards for Antimicrobial Susceptibility Testing; Twenty-fourth Informational Supplement. Jan; M100-S24, 34:1.

[18] Shanta, M. A., Ahmed, T., Uddin, M. N., Majumder, S. Hossain, M. S., and Rana, M. S. 2013. Phytochemical Screening and In Vitro Determination of Antioxidant Potential of Methanolic Extract of Stereospermum chelonoides. Journal of Applied Pharmaceutical Science. 3(3): 117-121. 
[19] Chandrashekhar, V. M., Muchandi, A. A., Sarasvathi, V. S and Muchandi, I. S. 2009. Free Radical Scavenging Activity of Stereospermum suaveolens DC: An In-vitro Evaluation. Pharmacologyonline. 1: 50-56.

[20] Balasubramanian, T., Senthilkumar, G. P., Karthikeyan, M., and Chatterjee, T. K. 2014. Therapeutic Effect of Stereospermum Suaveolens on Diabetic Nephropathy. Clinical \& Experimental Pharmacology. 4(5): 162

[21] Tor-Anyiin, T.A. and Anyam, J.V. 2013 Phytochemical Evaluation and Antibacterial Activity: A Comparison of Various Extracts from some Nigerian Trees. Peak Journal of Medicinal Plants Research. 1(2): 13-18.

[22] Haque, M. R., Rahman, K. M., Hasan, C. M., and Rashid, M. A. 2006. Antimicrobial and Cytotoxic Activities of Stereospermum chelonoides. Dhaka University Journal of Pharmaceutical Sciences. 5(1-2): 71-72.

[23] Rashedul, I. M., Rubina, A., Obaidur, R. M., Ahsanul, A. M., Muhammad, A., Dedarul, A. K., and Farhana, L. 2010. In Vitro Antimicrobial Activities of Four Medicinally Important Plants in Bangladesh. European Journal of Scientific Research. 39(2): 199.

[24] Boucher, H., Mille, L. G., and Razonable, R. R. 2010. Serious Infections Caused by Methicillin-Resistant Staphylococcus aureus. Clinical Infectious Diseases. 51 (2): S183-S197.

[25] Silva, A. C. O., Santana, E. F., Saraiva, A. M., Coutinho, F. N., Castro, R. H. A., Pisciottano, M. N. C., Amorim, E. C. L., and Albuquerque, U. P. 2013. Which Approach is More Effective in the Selection of Plants with Antimicrobial Activity? Evidence-based Complementary and Alternative Medicine. 308980.

[26] Rios, J. L., and Recio, M. C. 2005. Medicinal plants and antimicrobial activity. Journal of Ethnopharmacology. 100: 80-84.

[27] Bunkova, L., Bunka, F., Janis, R., Krejci, J., Dolezalkova, I., Pospisil, Z., Ruzicka, J., and Tremlova, B. 2011. Comparison of antibacterial effect of seven 1-monoglycerides on food-borne pathogens or spoilage bacteria. Acta Veterinaria Brno. 80: 29-39.

[28] Shaymaa, H., Abdel-Rhman, and Dina E. Rizk. 2016. Effect of tyrosol on Staphylococcus aureus antimicrobial susceptibility, biofilm formation and virulence factors. African Journal of Microbiology Research. 10(20): 687-693.

[29] Alves, M. J., Ferreira, I. C. F. R., Froufe, H. J. C. Abreu, R. M. V., Martins, A., and Pintado, M. 2013. Antimicrobial activity of phenolic compounds identified in wild mushrooms, SAR analysis and docking studies. Journal of Applied Microbiology. 115: 346-357.

[30] McGaw, L. J., Jäger, A. K., and Van Staden, J. 2002. Isolation of antibacterial fatty acids from Schotia brachypetala. Fitoterapia, 73: 431-433.

[31] Choi, J. S., Park, N. H., Hwang, S. Y., Sohn, J. H., Kwak, I. Cho, K. K., and Choi, I. S. 2013. The antibacterial activity of various saturated and unsaturated fatty acids against several oral pathogens. Journal of Environmental Biology. 34(4): 673-676.

[32] Sen, A., Dhavan, P., Shukla, K. K., Singh, S., and Tejovathi G. 2012. Analysis of IR, NMR and antimicrobial activity of $\beta$ sitosterol isolated from Momordica charantia. Science Secure Journal of Biotechnology. 1(1): 9-13.

[33] Tamokou, J. D. D., Kuiate, J. R., Tene, M., Kenla Nwemeguela, T. J., and Tane, P. 2011. The Antimicrobial activities of extract and compounds isolated from Brillantaisia lamium. Iranian Journal of Medical Sciences. 36(1): 24-31.

[34] Casillas-Vargas, G., Ocasio-Malavé, C., Medina, S., Morales-Guzmán, C., Del Valle, R. G., Carballeira, N. M. and Sanabria-Ríos, D. J. 2021. Antibacterial fatty acids: An update of possible mechanisms of action and implications in the development of the next-generation of antibacterial agents. Progress in lipid research. 101093. 